For referencing please use: Samaluk, B. (2014) Whiteness, ethnic privilege and migration: a Bourdieuian framework, Journal of Managerial Psychology, 29 (4): 370 - 388.

\title{
Whiteness, ethnic privilege and migration: a Bourdieuian framework
}

\author{
Author: Barbara Samaluk, Queen Mary, University of London \\ Accepted by Journal of Managerial Psychology on 10 November 2012 \\ Online version published in 2014 and available \\ at: http://www.emeraldinsight.com/doi/abs/10.1108/JMP-03-2012-0096?journalCode=jmp
}

\begin{abstract}
Purpose: The purpose of this paper is two-fold. Firstly it offers an innovative conceptual framework for exploring how whiteness shapes ethnic privilege and disadvantage at work. Secondly it offers empirical evidence of the complexity of ethnic privilege and disadvantage explored through experiences of migrant workers from post-socialist Central and Eastern Europe (CEE) on the UK labour market.
\end{abstract}

Design/methodology/approach: Using a Bourdieuian conceptual framework the paper begins from the historical and macro socio-economic context of EU enlargement eastwards in order to explore whiteness and the complexity of ethnic privilege at work through semi-structured in-depth interviews with 35 Polish and Slovenian migrant workers in the UK.

Findings: The findings highlight racial segmentation of the UK labour market, expose various shades of whiteness that affect CEE workers' position and their agency and point to relational and transnational workings of whiteness and their effects on diverse workforce.

Research limitations/implications: Research has implications for diversity policies within organisations and wider social implications for building solidarity amongst diverse labour. Future research could increase generalization of findings and further illuminate the complexity of ethnic privilege.

Originality/value: The paper contributes to management and organisational literature by offering a Bourdieuian conceptual framework for analysing whiteness and the complexity of ethnic privilege at work. It uncovers intersectional, transnational and relational workings of whiteness that shape ethnic privilege and disadvantage at work and speak of ongoing colonising and racialising processes that are part of contemporary capitalism.

Keywords: post-socialist Europe, postcolonial whiteness, ethnic privilege, migrant workers, UK, Bourdieu, Paper type: Research paper 
For referencing please use: Samaluk, B. (2014) Whiteness, ethnic privilege and migration: a Bourdieuian framework, Journal of Managerial Psychology, 29 (4): 370 - 388.

\section{Introduction}

This paper offers an empirical example of how the Bourdieuian conceptual trinity of field, habitus and capital can be utilised in order to explore how whiteness shapes ethnic privilege or disadvantage at work. Discussions of racism, whiteness and/or ethnic privilege are rarely tackled in organisational and management studies exploring workforce diversity (Acker, 2000; Cox Jr and Nkomo, 1990; Grimes, 2001; Nkomo, 1992; Tatli and Özbilgin, 2012). There is still also a lack of focus on labour migration processes in diversity research (Al Ariss, 2012, 2010; Al Ariss and Syed 2011; Bell et al., 2010; Dietz, 2010; Hakak et al. 2010, Healy and Oikelome, 2011; Hosoda et. al 2012). Furthermore there is not much research that specifically explores the relationship between whiteness and migration within organisations (Leonard, 2010b, 2010a). Nevertheless whiteness and ethnic segmentation at work have always been scrutinised in critical race and critical whiteness studies and are of growing interest to human geographers (Dyer et al., 2010; Hunter et al., 2010; Hunter, 2010; McDowell et al., 2007; McDowell, 2008; Wills et al., 2010).

Scholarship that puts historical emphasis on the construction of whiteness at work originates from the US (Allen, 1994, 1997; Du Bois, 1977/1935; Ignatiev, 1995; Roediger, 1991). In this scholarship whiteness was conceptualised as a resource. However, as researchers from other parts of the globe began to explore this topic, it also became evident that the US-based conceptions of whiteness are not easily translatable as they enter different historical and socio-economic contexts (Bonnett, 1998a, 1998b). This led to further engagement with postcolonial theory and the need to go beyond disciplinary boundaries and explore whiteness through intersectional, transnational and transdisciplinary approaches (Leonard, 2010b; Pedersen and Samaluk, 2012). These are important contributions that help us understand how capitalism has participated in the construction and maintenance of ethnic privilege and whiteness. 
For referencing please use: Samaluk, B. (2014) Whiteness, ethnic privilege and migration: a Bourdieuian framework, Journal of Managerial Psychology, 29 (4): 370 - 388.

Similar to the case of privileged class positions, whiteness often remains unchallenged, despite the fact that it can play an important role in structuring social relations (Weiss, 2010). In this regard Garner argues that whiteness can best be grasped as both a resource and a contingent social hierarchy granting differential access to economic, cultural and social capital and intersecting with different social categories that go beyond hegemonic white/non-white paradigms (Garner, 2006, p. 264, 75). By exploring whiteness one is able to recognise the importance of multiple standpoints that can expose the complexity of taken-for-granted privileges invested in ethnicity at work (i.e. ethnic privilege) without falling into an ethnicity paradigm (Grimes, 2001; Nkomo, 1992). And in exploring the migration of white CEE workers to the UK there is also the challenge of avoiding the equally problematic black and white paradigm whilst considering the spatial and temporal dimensions of migration (Garner, 2006; Pedersen and Samaluk, 2012). This research aims to address this challenge by exploring the following question: How does whiteness shape ethnic privilege or disadvantage at work?

This paper thus contributes to scholarship in two ways. Firstly it offers a Bourdieuian framework for the exploration of whiteness that takes into account contextual, relational, intersectional and transnational power relations that shape ethnic privilege and disadvantage at work. Secondly it offers empirical evidence of the complexity of ethnic privilege and disadvantage explored through experiences of migrant workers from Accession 8 (A8) [ $\left.{ }^{1}\right]$ countries on the UK labour market. The paper commences with the introduction of a Bourdieuian (1986; 1990a; 1990b; 1998; 2005) framework, which is followed by a macro level analysis that contextualises A8 labour migration to the UK. I then explain the method, data sample and analysis and discuss the findings that demonstrate how whiteness shapes ethnic privilege or 
For referencing please use: Samaluk, B. (2014) Whiteness, ethnic privilege and migration: a Bourdieuian framework, Journal of Managerial Psychology, 29 (4): 370 - 388.

disadvantage at work. Finally, the contributions of the paper, its implications and limitations are discussed.

\section{Bourdieuian conceptual framework}

I argue that Bourdieu's general theory of field, habitus and capital offers a useful theoretical and methodological framework for exploring the complexity of ethnic privilege and whiteness at work. Although Bourdieu has mostly been received as a theorist of class, his concepts have also been effectively used by scholars exploring racism and whiteness (Hage, 1998; Paynter, 2001; Puwar, 2004; Weiss, 2010). To move away from purely economic logic and to account for the structure and functioning of the social world, Bourdieu (1986) developed different forms of capital, namely economic, cultural, social and symbolic $\left.{ }^{2}\right]$. A Bourdieuian conception of different forms of capital provides a relational and multilevel framework for understanding capital accumulation and deployment (Al Ariss and Syed, 2011). It also provides an emic approach to intersectionality (Tatli and Özbilgin, 2012). As such it enables simultaneous exploration of cultural and economic processes of group formation from multiple levels and standpoints.

Starting with cultural capital Bourdieu argues that the accumulation of cultural capital in the embodied state, i.e., in the form of what is called culture, cultivation, Bildung, presupposes a process of embodiment that implies a labour of inculcation and assimilation' (1986, p. 244). So the extent to which different ethnic groups, 'races' $\left.{ }^{3}\right]$ or migrants are able to integrate and, for example, accumulate national cultural capital 'is linked to the cultural possessions and dispositions they bring with them' (Hage, 1998, p. 54). Or, in other words, embodied characteristics such as phenotype or language can play an important role in the accumulation of cultural capital. This also means that ethnicity and 'race' are very much embedded in the notions of nation and nationality (Balibar, 1991). In this regard Hage argues that 
For referencing please use: Samaluk, B. (2014) Whiteness, ethnic privilege and migration: a Bourdieuian framework, Journal of Managerial Psychology, 29 (4): 370 - 388.

'practical nationality is best conceived as a form of national 'cultural capital' (1998, p. 53). His conception of national cultural capital captures how whiteness defines symbolic belonging to the nation.

Moreover, it is important to note that an integral part of nationalism and racism is also sexism (Lutz et al., 1995; Balibar, 1991). Feminist scholars have argued that gender could also be understood as a form of embodied cultural capital, when it is converted into symbolic capital and as such legitimised (McCall, 1992; Skeggs, 2004). Research for instance informs how CEE migrant women's racialised sexuality and agency can be perceived as a threat to the national symbolic order (Cappusotti, 2007; Samaluk, 2009). This means that gender and sexuality in combination with other intersections can also play an important role in defining the 'national body'. This is of particular importance when looking at A8 labour migration to the UK, which consists of an equal, and occasionally higher, proportion of women to men (Currie, 2007; Dyer et al., 2010; Vertovec, 2006).

The above arguments suggest that different intersections can also position white minorities within the hierarchy of acceptability. This demonstrates the importance of identifying 'race', ethnicity and colour as separate yet relational criteria (Garner, 2006; Grimes, 2001; Nkomo, 1992). In late capitalism, asylum seekers and economic migrants are increasingly being used by political elites and far-right groups as scapegoats for the diminishing of the welfare state and perceived by the working class as competitors for scarce resources (Garner 2006). With the opening of EU borders for internal migration and the deepening of economic crises, A8 and A2 $\left.{ }^{4}\right]$ workers are increasingly becoming targets of workers protests and being used by politicians as scapegoats for economic and social troubles[5]. In this regard it is crucial not to lose sight of the material aspects of analysis in order to realise that class, just like gender and 'race', is an active, ongoing, mutually reproduced process 
For referencing please use: Samaluk, B. (2014) Whiteness, ethnic privilege and migration: a Bourdieuian framework, Journal of Managerial Psychology, 29 (4): 370 - 388.

that can best be understood from different standpoints (Acker, 2000). Therefore apart from cultural and symbolic capital, it is also economic and social capitals that should be taken into account when exploring how whiteness shapes ethnic privilege or disadvantage at work. However, when exploring whiteness in relation to migration, it is crucial to look not just at intersections of categories of difference, but also at how these intersections are shaped by temporal and spatial dimensions (Leonard, 2010b). This further brings us to consideration of the concept of habitus and field.

Systems of inequality can only fully function when they are objectified not only in things but also in bodies. Habitus functions as an 'embodied history, internalized as a second nature that is conveniently forgotten as history' (Bourdieu, 1990a, p. 56). Also whiteness can be described as an ongoing cultural historical concept that has been inherited from the history of European colonialism (Ahmed, 2007; Hage, 1998). This means that whiteness can also function as an embodied and forgotten history; therefore, it could be treated as one of the constitutive dimensions of habitus. In other words, whiteness can act as 'ontological denial' (Puwar, 2004, p. 131). The concept of habitus enables us to uncover how, on one hand, whiteness travels with migrants as an embodied history linked to colonialism. On the other hand, it can be used to explain how whiteness is reshaped through cultural-economic practices that reinscribe colonialization by appropriating migrants' capitals. This further calls for postcolonial and transnational approaches to whiteness that are able to grasp spatial and temporal dimensions in order to uncover multiple and ongoing power relations (Leonard, 2010b; Lopez, 2005). Ultimately this brings us to the concept of the field.

In analytical terms the field is defined as 'a network, or a configuration, of objective relations between positions' (Bourdieu and Wacquant, 1992, p. 97). In order to describe it Bourdieu often uses the metaphor of the game in which players enter with different capitals that determine their value in the game. The concept of the field 
For referencing please use: Samaluk, B. (2014) Whiteness, ethnic privilege and migration: a Bourdieuian framework, Journal of Managerial Psychology, 29 (4): 370 - 388.

points to the ways in which social relationships are structured by power (Levitt and Schiller, 2004). The understanding of habitus formation must thus be positioned 'within social, political and economic fields of the sending country and the changes it undergoes in these fields in the receiving country' (Loyal, 2009, p. 417). Although the nation states are crucial in exploring migratory processes, it is also important to take into account that the state not only influences but is itself influenced by other fields, including the global economic field (Bourdieu, 1998, 2005; Jessop and Oosterlynck, 2008). Regimes of governance are thus increasingly subject to meta-governance, such as the European Union (Fairclough, 2005, p. 60). This also reflects on the labour market and organisations that can also be analysed as fields that are in mutual relationship with other fields (Özbilgin and Tatli, 2005).

As Metcalfe and Woodhams argue relationality and intersectionality are more than organisation concepts; they span across boarders and contribute to structural inequalities on global and local levels, as well as form possibilities for common struggles (2012, p. 133). By recognising that migrants identify and are defined across transnational fields, we are able to understand that they occupy different gender, 'racial' and class positions within different places at the same time and also that these can change through time (Levitt and Schiller, 2004, pp. 1015). This enables the exploration of whiteness not just as context specific, but also as a transnational and relational hegemony (Pedersen and Samaluk, 2012). To further strengthen this argument I now continue with contextualising A8 labour migration by exploring the relationship amongst transnational fields.

\section{Contextualising A8 labour migration through an exploration of the relationship amongst transnational fields}

More than twenty years after the fall of the Berlin wall there is still a tendency to construct all post-socialist Central and Eastern European (CEE) countries and their 
For referencing please use: Samaluk, B. (2014) Whiteness, ethnic privilege and migration: a Bourdieuian framework, Journal of Managerial Psychology, 29 (4): 370 - 388.

nationals as the same $\left[{ }^{6}\right]$. This points to the continuation of colonising practices in contemporary Europe that need to be taken into account when looking at very recent history and its effects on migrant labour. In this regard Böröcz (2001) argues that Eastern Enlargement was characterised by institutional elements of colonial imperial structure that combined four mechanisms of control, namely unequal exchange, coloniality, export of governmentality and geopolitics. From this perspective accession countries were evaluated through various means and as such reinvented with the selective aggregation of facts and fiction. These have drawn on the familiar ideological Cold War divide and on the selective assessment of applicant's economic and political development with regard to an idealised EU[7] state (Kovacs, 2001; Kovacs and Kabachnik, 2001; Sher, 2001). This situated CEE countries as stuck in the past and legitimized the framing of the enlargement as the EU's civilizing mission towards its inferior 'East'. This legitimization enabled economic colonialization to EU based corporations that are today the biggest investors in CEE (Böröcz, 2001). However colonialization did not manifest itself only in control over and ownership of economic assets, but also in political influence on (meta)governance (Bohle, 2006).

The Enlargement process was bureaucratic, technocratic and elitist. As such it produced new discourses, the so-called 'cognitive Europeanization', that has completely altered the way in which policies are formulated and executed in CEE states (Kuus, 2004; Lendvai, 2004, p. 329). This discourse was not simply imposed, but was propagated by elites in member states through the narratives of a 'return to Europe' that painted the EU as the panacea (Močnik, 2002). In this sense Kiossev talks about 'self-colonising cultures', referring to the colonization of consciousness in which these cultures traumatize themselves by adapting their own inferiority (2010, p. 2). In terms of ethnic privilege and whiteness it is also important to note that (self) colonialization also operates in localised racialising $\left[^{8}\right]$ practices within CEE (BakićHayden, 1995; Imre, 2005; Kuus, 2004; Todorova, 1997). 
For referencing please use: Samaluk, B. (2014) Whiteness, ethnic privilege and migration: a Bourdieuian framework, Journal of Managerial Psychology, 29 (4): 370 - 388.

Europeanization thus functions as a hegemony that has, due to major transformations in modes of production, social and political-ideological relations, shifted towards a neoliberal form (Bohle, 2006). For example, by imposing neoliberal policies on A8 states, the EU and other international actors were actively participating in implicit approval of certain ambiguous social protection reforms that have created conditions for social dumping $\left[{ }^{9}\right]$ practices (Albert and Standing, 2005; Ferge, 2000; Vaughan-Whitehead, 2003). As the actual date for the enlargement approached, the fears of social dumping grew and affected EU's policy with regard to the movement of labour (EC, 2000). Unequal power relations amongst states and fears of social dumping in terms of movement of labour finally resulted in transitional measures that restricted free movement of A8 labour and effectively produced not just formal second-class European citizens, but also subordinate cultural one (Ong, 1996; Tutti, 2010).

In this context the British government adopted a Worker Registration Scheme (WRS) that allowed A8 nationals to work in the UK, but prevented them from accessing unemployment benefits unless they had been working continuously in the UK for more than one year (Doyle et al., 2006). WRS was not just introduced to prevent A8 nationals from accessing welfare benefits, but also allowed the state to monitor A8 labour and its impact on the UK economy (HO, 2010). This policy alignment was in line with governmental plans to limit non EU/EEA $\left[{ }^{10}\right]$ labour migration, which also had important racial and religious dimensions (Anderson et al., 2006; Cheong et al., 2007; McDowell, 2009). All this is also reflecting in the practices of employers and employment agencies.

In the UK labour market A8 workers are simply referred to as 'Eastern Europeans' and defined through the narratives of hard work, high work ethics and their 
For referencing please use: Samaluk, B. (2014) Whiteness, ethnic privilege and migration: a Bourdieuian framework, Journal of Managerial Psychology, 29 (4): 370 - 388.

willingness to work without complaint (Anderson et al., 2006; Samaluk 2011; Wills et al., 2010). Due to their unmarked skin colour they are specifically desired for lowpaid service sector jobs (Dyer et al., 2010; McDowell et al., 2007). As a result A8 workers often face de-skilling, devaluation and racism (Anderson, 2000; Currie, 2007; Downey, 2008; Stevenson, 2007; Wills et al., 2010). They are used by employers to fill less skilled jobs, are more likely to be underpaid, are often utilised for temporary work and are less likely to be on standard contracts of employment (Anderson et al., 2007; MacKenzie and Forde, 2009; McKay, 2009). At the same time A8 workers can also discriminate against their fellow co-nationals and/or other black and ethnic minority (BEM) groups (Samaluk, 2009; Wills et al., 2010; McDowell et al., 2007). All this research evidence point to multiple power relations and the complexity of disadvantage and privilege that is explored through the experiences of Polish and Slovenian workers in the UK, outlined further below.

\section{Method, sample and data analysis}

This research draws on 35 semi-structured interviews with white Polish and Slovenian workers living and working in London and south England. This research project was born out of professional interests and my personal experiences as a migrant from the CEE to the UK. My own position, as a white migrant woman, constructed an imagined sameness between myself and interviewees, which in some ways enabled easier access to some participants and at times made interviewees more comfortable to talk about the way they are positioned and treated on the UK labour market. But on the other hand this also made it more difficult to talk about whiteness, because interviewees would often assume that I would understand their unspoken assumptions. In order to mitigate this I engaged with methodological tensions between the production of sameness and otherness and aimed to address these assumptions through in-depth questions that provided additional explanations or examples (Frankenberg, 1993; Gunaratnam, 2003). Interviews lasted between one 
For referencing please use: Samaluk, B. (2014) Whiteness, ethnic privilege and migration: a Bourdieuian framework, Journal of Managerial Psychology, 29 (4): 370 - 388.

and two hours and explored reasons and motivation for migration, migrants' experiences in accessing work and working in the UK and strategies to overcome difficulties arising from work and recruitment process. Workers were accessed through on-line forums, communities and organisations that connect Polish or Slovenian migrants in London or the UK, as well as recruitment agencies that specialise in supplying A8 workers in the UK. Amongst interviewees there were 23 women and 12 men, between 23 and 42 years old and with good English language skills. A summary of the sample demographics is presented in Table I.

[Table I: Sample profile should be inserted here]

All interviews were conducted in English[11] and were digitally recorded and later transcribed. Data was analysed through the process of coding and the use of QSR NVivo software. Coding procedure consisted of open coding, axial coding and selective coding (Strauss and Corbin, 1990). The coding process was informed by emerging codes as well as the pre-established framework and orienting concepts (Layder, 1998). In the first stage I closely examined the data, in order to identify key codes. Amongst identified codes were categories of difference ('race', ethnicity, gender, class, age), as well as migration status, language, work ethics, habitus, place. The second stage involved reading and re-reading the interview transcripts in order to identify relationships between codes; upon which major themes were identified. While initial codes encompassed the mixture of social categories and concepts, the themes focused on processes that highlight the relationships amongst them and are described under specific subheadings in the findings. Finally, in the last stage of coding, I conceptualised these relationships at a higher level of abstraction, by using a Bourdieuian conceptual framework.

\section{Findings}


For referencing please use: Samaluk, B. (2014) Whiteness, ethnic privilege and migration: a Bourdieuian framework, Journal of Managerial Psychology, 29 (4): 370 - 388.

Below I present the findings which illustrate how whiteness shapes ethnic privilege or disadvantage at work. This also points to the usefulness of a Bourdieuian framework in exploring whiteness. I demonstrate that a Bourdieuian framework enables the exploration of processes of power on transnational fields that can uncover contextual, intersectional, transnational and relational workings of whiteness at work. The findings illuminate racial segmentation of the UK labour market, expose intersectional workings of whiteness that affect CEE workers' position and their agency and expose relational and transnational workings of whiteness and their effects on diverse workforce.

\section{Intersectional workings of whiteness and racial segmentation of labour}

In this section I discuss the relationship amongst fields, habitus and capitals in order to expose intersectional workings of whiteness that affect workers' position and their agency in the UK labour market. Many of my interviewees felt that class represents the biggest challenge for equality in the UK. But as they started explaining what they mean by class, it soon became apparent that class is constructed through various intersections that are embodied in migrants' habitus. This is vividly explained by Marjan:

'You have to realise that you will never have equal chance than somebody who really feels the language. One thing which was maybe the hardest thing for me is to realise that there are classes, there are social classes...I was high class before, now I'm the lowest class.... You can reach it in the sense of money, but you can not reach it in the sense of appreciations and social appreciations. No, because it's upbringing, it's the school which you were in, communities. It forms from your upbringing and you can not deny it. It is your name....It stopped me; it stopped me for some time. It was demotivational, absolutely demotivational'. 
For referencing please use: Samaluk, B. (2014) Whiteness, ethnic privilege and migration: a Bourdieuian framework, Journal of Managerial Psychology, 29 (4): 370 - 388.

Marjan's account shows how his cultural capital gets devalued as he enters a new field. Because he is embodying a history of another place his cultural capital gets appropriated in a way that disables him from gaining the social appreciation and legitimacy that would allow him to enter society on equal terms. Data shows how Marjan's language and name function as embodied markers that objectify cultural inferiority. Due to devalued cultural capital A8 workers also often face downward professional mobility. This can have negative effects on workers' agency and can disable their upward professional mobility at least for some time. Findings thus point to the cultural construction of class that further has important racial, gender and age dimensions.

Many young female CEE workers recalled how they were perceived or treated in a sexualised way. Through colonial and racialised processes their embodied cultural capital gets redefined and can be turned into economic capital for specific jobs. As Ania explains white, young, CEE women are desirable for front-line service sector work, but they face problems when trying to reach higher positions:

'I think I was the only Polish girl within the company who actually got the manager's job... Because the company I worked for was, they were very posh and English and all that stuff... There was a certain appearance...well definitely smiley... but flirtatious...They were OK with having Polish as the bar staff...but they were not very keen on promoting them... I think it's in the City I think they're quite racial here, when it comes to colour of your skin...it was definitely they would prefer to hire white people...And then of course the kitchen staff, we had a lot of kitchen staff Asian and African.'

Ania's account demonstrates that white skin provides an economic capital in frontline service sector jobs and within specific places reserved for upper classes of 
For referencing please use: Samaluk, B. (2014) Whiteness, ethnic privilege and migration: a Bourdieuian framework, Journal of Managerial Psychology, 29 (4): 370 - 388.

society. Findings expose institutional racism and whiteness that is maintained and reproduced through managerial practices within organisations and customers' consumption of workers' identities. This also points to the relationship between the organisational field and the meta-field. For Bourdieu the nation-state represents a sort of meta-field because it has the monopoly over legitimate physical and symbolic violence; it performs diagnostics of individuals and groups and assigns them specific identities (Bourdieu, 1990b, p. 136; Bourdieu and Wacquant, 1992). This entails that in each nation state there exists a normative habitus upon which Otherness is constructed, or upon which migrants' capitals get defined, appropriated and translated. Accounts have demonstrated that normative habitus is defined upon Englishness that is characterised with whiteness, maleness and normative language. While CEE workers embody a different history their whiteness gets shaded through the appropriation of capitals that assign them specific value and class position within the hierarchy of acceptability amongst diverse groups of workers.

Although phenotypical whiteness can provide CEE workers with a certain privilege, this can only be utilised within the assigned frame of opportunities. As the above accounts have demonstrated that there are various shades of whiteness that are defined through intersectional imaginaries within specific national context and result in racial segmentation of diverse labour, we must not forget that whiteness also operates as a transnational and relational hegemony (Pedersen and Samaluk, 2012).

\section{Transnational and relational workings of whiteness}

This section examines relationships amongst transnational fields and their effects on habitus and capitals in order to expose the relational and transnational workings of whiteness that can function as ethnic privilege or disadvantage at work, as invisibilization of racism or as a tool to compete for scarce resources. In order to understand these complex power relations it is important to take into account 
For referencing please use: Samaluk, B. (2014) Whiteness, ethnic privilege and migration: a Bourdieuian framework, Journal of Managerial Psychology, 29 (4): 370 - 388.

migrants' places of origin that co-define their habitus. Data shows that racialised 'Europeaness' hidden under culturalist discourse plays an important role in what seems to be a modern version of nationalism that has become effectively transnational (Pedersen and Samaluk, 2012). Pawel's account demonstrates how a sense of place narrated through 'Europeaness' points to imagined sameness that can affect self-positionality towards other BEM groups:

'I am some kind of nationalist, but I am not talking about Poland, England, Sweden or France, I am talking about Europe'.

These exposed transnational workings of whiteness uncover embedded historical power relations that are still present and shape contemporary work relations. Here it is important to note that CEE countries used to be former colonies of European empires and have as such also inherited the Enlightenment ideas of nationalism and racism (Imre, 2005). Whiteness thus travels with CEE migrants as an embodied history to their new destinations and can form the basis for the construction of imagined sameness. This imagined sameness is built upon shared history of European colonialism that was characterised with whiteness, maleness and Christianity (Ponzanesi and Blaagaard, 2011, p. 3). However this does not only mean that CEE workers bring these embedded power structures with them but also that they re-learn and appropriate them according to historical and on-going power structures operating with the UK. In this regard Anna's account shows how 'Europeaness' affects informal relationships at work:

'I've noticed that people usually gather around ethnic group and religious group. So for example I had a Muslim man in the office...he did not socialise with us, because he couldn't drink... I've noticed, even in my peer group now and it's made out mostly of British people, there is no black person, there is no Asian person. We are all European, 
For referencing please use: Samaluk, B. (2014) Whiteness, ethnic privilege and migration: a Bourdieuian framework, Journal of Managerial Psychology, 29 (4): 370 - 388.

Irish, Polish and British, English specifically.... On the professional level I've noticed people have no major problems, I don't see racism, but when it comes to outside of work relations. I've got the feeling that people gather most likely with people of their own background'.

Anna's account shows how some appropriations of CEE's cultural capital can be turned into social capital that grants them ethnic privilege in accessing informal networks at work. This speaks of institutionally embedded whiteness that can in effect also be turned into economic capital, when it comes to promotions, training and opening of new opportunities.

By focusing on the processes of power and the constant rewriting of history, I am at the same time not losing site of relational and multidimensional power relations where whiteness can also function to invisibilise racisms. In this regard Lentin and Titley (2011) also point to the detrimental effects of politics of diversity that has become central in the privatization of 'race' and invisibilization of racism. Data demonstrates that CEE workers often experience blatant racism, both in and outside work, in the form of racist jokes, attitudes or practices. Nina explains how, due to her embodied cultural capital, her supervisor felt legitimised to make racist comments:

'I had my supervisor who made a comment that was inappropriate and I was very, very upset then...We were told we are going to lose the jobs and what she said to me was: 'Oh, are there no jobs in your country!'... I expected an apology in a way, but she didn't want to admit that he was being inappropriate... I don't think she would even think about saying this to my colleague who was from Caribbean, imagine...I think she would not do that because of the appearances, because their appearance is different. If you just look at me, by just looking, I don't have different colour of the skin. I don't see her saying that to an Asian person or black person at all.' 
For referencing please use: Samaluk, B. (2014) Whiteness, ethnic privilege and migration: a Bourdieuian framework, Journal of Managerial Psychology, 29 (4): 370 - 388.

The invisibility of intersecting modalities in the construction of racism and whiteness can thus result in political disempowerment that excludes CEE workers from equality and diversity policies at work. In this regard, data demonstrates that the cultural capital of CEE workers can also entail a lack of symbolic capital that would recognise them as potential victims of racism and legitimise their status as marginalised groups entitled to positive measures. The focus on ongoing racialising and colonising power relations further offers an understanding that racisms play a crucial role in workers' competition for scarce resources.

Data demonstrates that workers are using their embodied cultural capital to legitimise their privilege in accessing resources. They are using various racialised markers to re-claim their entitlement to economic capital. In the individualised logic of contemporary capitalism where diversity politics have become an important part of managerial practices, the doing of 'race' is not only imposed on workers, but becomes part of their personal politics in their precarious existence (Lentin and Titley, 2011). Data informs of division amongst and within different CEE groups, as well as resentment towards other BEM groups. Anna's account, on the other hand demonstrates how CEE workers can be equally resented by other BEM groups:

'I've seen a couple, a black woman and a white man and she was complaining to him. 'What are all these Polish people coming here for!' and she was complaining 'Why are they taking the jobs!' And she's from Africa, she came here as well, or her mother maybe. So I just kind of thought, it's not quite fair for her to judge us for arriving, if she herself is from African background'.

At the same time this excerpt also demonstrates how embodied cultural capital of established black ethnic minorities and older generations of migrants gets 
For referencing please use: Samaluk, B. (2014) Whiteness, ethnic privilege and migration: a Bourdieuian framework, Journal of Managerial Psychology, 29 (4): 370 - 388.

appropriated in order to deny their belonging to the nation. In the above account we can see how in Anna's eyes the black woman embodies a history of another place that denies her belonging to the 'national body'. Data thus points to a relational nature of racism, where ethnic privilege or disadvantage can be assigned by anyone to everyone depending on certain time and place in history. This can play an important role in the way workers position themselves, their habitus and consequently how they appropriate their cultural capital in the rat-race for scarce resources.

\section{Discussion}

By exploring how whiteness shapes ethnic privilege or disadvantage at work, this study contributes in two ways. Firstly it provides empirical evidence of the complexity of ethnic privilege and disadvantage at work, and secondly it offers a Bourdieuian framework for the exploration of whiteness at work. As such this study contributes to the debate on theoretical and methodological expansions of research focusing on migration and diversity at work (Al Ariss, 2010; Al Ariss and Syed, 2011; Al Ariss et al., 2012; Metcalfe and Woodhams, 2012). It also offers new insights for research exploring the relationships between whiteness, migration and work (Dyer et al., 2010; Leonard, 2010b; 2010a; McDowell et al., 2007; McDowell, 2008; Wills et al., 2010).

More precisely the paper contributes by going beyond ethnicity and black and white paradigms that are still prevalent in most managerial and organisational scholarship exploring work processes characterised by mobile and diverse labour. As such it is able to dig out how multiple, relational, transnational, historical and emerging power relations invested in whiteness shape ethnic privilege and disadvantage at work and how this affects contemporary labour markets and (self) positioning of a diverse workforce. The paper further contributes by offering a framework which enables the 
For referencing please use: Samaluk, B. (2014) Whiteness, ethnic privilege and migration: a Bourdieuian framework, Journal of Managerial Psychology, 29 (4): 370 - 388.

incorporation of spatial and temporal dimensions in the analysis. Evidence suggests that CEE migrant workers are enjoying a certain ethnic privilege due to their whiteness, but are also perceived as inferior, as lower class and as suited for low paid jobs. The data reveals how different intersections get appropriated in a new place. Evidence suggests that ethnicity, 'race', gender and age are redefined through these spatial and temporal dimensions and as such become constitutive of a new, subordinate class position. This extends the findings of previous research focusing on discrimination faced by migrant workers on the labour market (Dietz, 2010; Hosoda and Stone-Romero, 2011). By using a relational and multilevel framework it is able to explain why, for instance, language, accents and names become symbolic signs of ethnic disadvantage in the labour market.

This framework further enables the exploration of class formation, not just within production but also within consumption processes. Evidence suggests that diverse and mobile labour is constructed within the hierarchy of acceptability also through customer service experience and customers' consumption of workers' identities. This points to the relationship between organisations and the wider context in which historical and underlying power structures become important in positioning diverse and mobile workforce. A relational framework further exposes how workers themselves utilise their (self) identities in order to compete on the labour market. The findings demonstrate that temporal and spatial dimensions can play an important role in the way workers position themselves, their habitus and consequently how they appropriate their cultural capital in the rat-race for scarce resources. This offers an explanation of what lies beneath the differential (self) positioning or agentic choices of workers. This adds new insight to research exploring migrants' mobilization of capitals and their strategies in overcoming barriers at work (Al Ariss and Syed, 2011; Hakak et al., 2010). By exposing subtle and ongoing power relations this paper contributes by uncovering multiple and ongoing colonial projects, that 
For referencing please use: Samaluk, B. (2014) Whiteness, ethnic privilege and migration: a Bourdieuian framework, Journal of Managerial Psychology, 29 (4): 370 - 388.

form an important part of contemporary capitalism and thus shape relations amongst the members of diverse workforce within organisations. Ultimately this offers new insights to managerial and organisational scholarship that has emphasised the importance of ongoing and intersectional power relations within contemporary labour markets and organisations (Acker, 1990, Healy et al., 2011).

\section{Policy and wider social implications}

Several findings of this study carry policy and practical implications. Data show that due to racialization practices many highly skilled CEE workers lacked opportunities for development and utilization of their talent. Diversity policies of organisations should thus go beyond ethnicity and black and white paradigms to recognise ongoing colonising processes hidden under a seemingly 'meritocratic' capitalist system and uncover implicit assumptions which render specific forms of cultural capital valuable and others unrewarded. By betting on translations of capitals based on stereotypical assumptions instead of recognising the true value of cultural capital that migrants bring with them, organisations not only lose talent, but also disregard migrants' social capital that could become an important asset for organisations operating across transnational fields.

A transnational and relational focus does not only allow us to discover differences amongst diverse groups, but also to understand commonalities of exclusion that can have wider social implications. The data indicate that, despite being white, CEE workers face structurally similar practices of exclusion to other BEM workers in the UK (Healy et al., 2011). Equality and diversity frame within organizations should thus apart from colonial history take into account also new and emerging colonial projects that produce a new history. The awareness of ongoing colonising processes can form the basis for solidarity and collective action amongst diverse workers that in fact suffer from similar structural forms of exclusion and precarious existence. 
For referencing please use: Samaluk, B. (2014) Whiteness, ethnic privilege and migration: a Bourdieuian framework, Journal of Managerial Psychology, 29 (4): 370 - 388.

\section{Limitations and opportunities for future research}

Findings of this qualitative study derive from workers' perceptions and understandings of their experiences. Given its exploratory nature, this study is not representative enough to allow for a generalization of the findings. However it has illuminated how whiteness shapes ethnic privilege and disadvantage at work and offered a conceptual framework for its exploration. The paper could also benefit from more in-depth exploration of how workers negotiate, resist or transform power structures. It would be worthwhile if future research focused on strategies of CEE workers in overcoming barriers at work. The scope of this paper has also not allowed the exploration of differences between and amongst Polish and Slovenian workers. Future research should thus explore the complexity of ethnic privilege and disadvantage amongst and within diverse CEE ethnic, religious and national groups. Finally, ongoing colonizing processes could further be scrutinised by future studies exploring how these same groups are positioned in different states or regions within and outside Europe.

\section{Notes}

\footnotetext{
${ }^{1}$ Accession 8 (A8) stands for eight post-socialist Central and Eastern European countries (Estonia, Latvia, Lithuania, Poland, Czech Republic, Slovakia, Hungary and Slovenia) that have joined the EU in 2004.

${ }^{2}$ In Bourdieu's (1986) typology economic capital can immediately be converted into material value. Cultural capital is on the other hand accumulated through the process of 'cultivation' and is, as such, of symbolic or misrecognised material value on the labour market (Brubaker, 2005). Social capital, consisting of networks, acquaintances and connections can be of substantial material value in all aspects of life, but is also not immediately apparent (Bourdieu, 1986). The characteristic of all forms of capital is that they have the potential of being transformed into one another. To this Bourdieu later added symbolic capital that represents the translation of any of the above three capitals in order for them to get recognition and legitimacy on the field (Bourdieu and Wacquant, 1992).

${ }^{3}$ I am using the term 'race' in quotation marks in order to denote that there are no natural or inner attributes that construct 'race' and racial identities but rather a set of socially ascribed racial characteristics that can take different shapes and forms in different historical and socio-economic contexts (Gunaratnam, 2003).

${ }^{4}$ A2 stands for Accession 2 countries (Bulgaria and Romania) that joined the EU in 2007.
} 
For referencing please use: Samaluk, B. (2014) Whiteness, ethnic privilege and migration: a Bourdieuian framework, Journal of Managerial Psychology, 29 (4): 370 - 388.

${ }^{5}$ CEE migrants became targets of protesters in 2009 when they staged a demonstration to call for jobs to be given to British people (Guardian, 2009). And the anti-immigration Freedom Party (PVV) in Netherlands launched the website in 2012 (http://www.meldpuntmiddenenoosteuropeanen.nl/) to collect complaints about 'Eastern Europeans' from among the Dutch population.

${ }^{6}$ Research informs that incorrect, oversimplified and dangerous homogenization of CEE is visible in public discourses, knowledge production, policy making and practices on national and supra-national level (Böröcz, 2001; Inotai, 2002; Kideckel, 1996; Kürti, 2008; Slovova, 2006).

${ }^{7}$ EU refers to European Union.

${ }^{8}$ Although countries and people of CEE are, from the western perspective, often all imagined as the same (Forrester et al., 2004), this perception was quite different from the perspective of CEE countries themselves that never ceased to feel distinct from one another. This is visible in racialising practices operating within CEE. Research informs that, for instance, Slovenian media represent Slovenia as 'Europe' which is differentiated from 'the Balkans' (Močnik, 2002). And former Yugoslavian republics tend to differentiate themselves from former Eastern bloc countries (Marc, 2009; Todorova, 1997). They also use the positive image of Austro-Hungarian empire as part of their imagined cultural belonging in order to establish a link to 'European culture' (Hipfl and Gronold, 2011). People in the Balkans thus 'perceived each other as both colonial rulers and as colonial subjects' (Bjelić, 2002, p. 6). Also 'Estonian and Latvian intellectuals have been among the most adamant in casting Russia as inherently un-European' (Kuus, 2004: 480). The above examples clearly point to localised racialised practices and demonstrate that the perception of the 'East' and the 'West' changes through spatial and temporal dimensions (Kuus, 2004).

${ }^{9}$ According to Albert and Standing social dumping 'implies situations in which standards in one country are lowered relative to what they would have been because of external pressure from all or part of the global economic system (2005, p. 99). This could take different forms, such as for instance the relocation of production to low cost countries, or employers taking advantage of migrant labour, etc. Social dumping is thus clearly connected with movement of capital, goods, services and labour and is possible because of inequalities within global economic field (Bourdieu, 2005).

${ }^{10}$ EEA refers to European Economic Area.

${ }^{11}$ Since this research project is producing knowledge in English language and has been conducted in a UK context by a researcher and with research participants who are embodying different places, it is also engaging with the epistemology of translation that views translators of research findings as active participants in knowledge production (Temple, 1997; Temple and Edwards, 2008). In order not to lose meaning through my own translation and interpretation, I let my research participants translate themselves into English language, the language of the new meta-field. This decision also affected my sample that consists solely of workers with good English language skills. By doing this I did not only democratized the research process, but also exposed participants' encounters with power structures within this new field. Although all my interviewees were speaking English language, they often faced exclusion because their accents or cultural background disabled them from speaking its legitimate form (Bourdieu 1991; Puwar 2004). As Temple (1997) argues, engaging with the epistemology of translation equips us with the awareness that translations provide not just constructs of concepts from a specific perspective, but also from a specific history. By allowing my interviewees to translate themselves, I could uncover how concepts with a different history meet a new history once they enter a new field. Their self-translation enabled me to find out what is hidden in concepts such as 'race', racism, class, gender, etc.. Migrants' gaze and their translations enabled me to uncover multiple power relations that are often hidden from view if approached through an ethnocentric gaze and without taking into account spatial and temporal dimensions. 


\section{References}

Acker, J. (2000), “Revisiting class: thinking from gender, race, and organizations", Social Politics: International Studies in Gender, State E Society, Vol. 7 No. 2, pp. 192-214. Ahmed, S. (2007), “A phenomenology of whiteness", Feminist Theory, Vol. 8 No. 2, pp. 149-168.

Al Ariss, A. (2010), “Modes of engagement: migration, self-initiated expatriation, and career development", Career Development International, Vol. 15 No. 4, pp. 338-58.

Al Ariss, A. and Syed, J. (2011), “Capital mobilization of skilled migrants: a relational perspective", British Journal of Management, Vol. 22 No. 2, pp. 286-304.

Al Ariss, A., Koall, I., Özbilgin, M. and Suutari, V. (2012), “Careers of skilled migrants: towards a theoretical and methodological expansion", Journal of Management Development, Vol. 31 No. 2, pp. 92-101.

Albert, J. and Standing, G. (2005), “Social dumping, catch-up, or convergence? Europe in a comparative global context", Journal of European Social Policy, Vol. 10 No. 2, pp. 99-119.

Allen, T. W. (1994), The invention of the white race, Verso, London.

Anderson, B. (2000), Doing the Dirty Work? The Global Politics of Domestic Labour, Zed Books, London.

Anderson, B., Clark, N., and Parutis, V. (2007) New EU members? Migrant Workers' Challenges and Opportunities to UK Trade Unions: a Polish and Lithuanian Case Study, TUC, London.

Anderson, B., Ruhs, M., Rogaly, B. and Spencer, S. (2006), Fair enough? Central and East European migrants in low wage employment in the UK, COMPAS, Oxford.

Bakić-Hayden, M. (1995), “Nesting orientalism: the case of former Yugoslavia”, Slavic Review, Vol. 54 No. 4, pp. 917-31.

Balibar, E. (1991), "Racism and Nationalism”, in Balibar, E. and Wallerstein, I. (Ed.), Race, Nation, Class - Ambiguous Identities, Verso, London, pp. 37-68. 
Bell, M.P., Kwesiga, E.N., and Berry, D.P. (2010), “Immigrants: The new 'invisible men and women' in diversity research", Journal of Managerial Psychology, Vol. 25 No. 2, pp. 177-88.

Bjelić, D. I. (2002), “Introduction: Blowing up the 'bridge”, in Bjelić, D. I. (Ed.), Balkan as metaphor, MIT Press, London, pp. 1-20.

Bohle, D. (2006), “Neoliberal hegemony, transnational capital and the terms of the EU's eastward expansion", Capital E Class, Vol. 30 No. Spring, pp. 57-86.

Bonnett, A. (1998a), “How the British working class became white: The symbolic (re) formation of racialized capitalism", Journal of Historical Sociology, Vol. 11 No. 3, pp. 316-40.

Bonnett, A. (1998b), "Who was white? The disappearance of non-European white identities and the formation of European racial whiteness", Ethnic and Racial Studies, Vol. 21 No. 6, pp. 1029-55.

Böröcz, J. (2001), “Introduction: Empire and Coloniality in the 'Eastern enlargement' of the European Union", in Böröcz, J. and Kovasc, M. (Ed.), Empire's New clothes: Unveiling EU Enlargement, Central Europe Review, Telford, pp. 4-51.

Bourdieu, P. (1986), "The forms of capital”, in Richardson, J.G. (Ed.), Handbook of Theory and Research for the Sociology of Education, Greenwood, London, pp. 241-258.

Bourdieu, P. (1990a), The logic of practice, Polity, Cambridge.

Bourdieu, P. (1990b), In other words, Stanford University Press, Stanford, CA.

Bourdieu, P. (1991), Language and symbolic power, Polity, Cambridge.

Bourdieu, P. (1998), On Television, NY Press, New York.

Bourdieu, P. (2005), The social structures of the economy, Polity, Cambridge.

Bourdieu, P. and Wacquant, L.J.D. (1992), An Invitation to Reflexive Sociology. Polity Press, Cambridge. 
Brubaker, R. (2005), "Rethinking classical theory: The sociological vison of Pierre Bourdieu" in Schwartz, D. L. and Zolberg, V. L. (Ed.), After Bourdieu: Influence, Critique, Elaboration, Kluwer Academic Publishers, London, pp. 25-64.

Cappusotti, E. (2007), “Moderrnity versus Backwardness: Italian Women-s Perceptions of Self and Other", in Passerini, L., Lyon, D., Capusotti, E. and Laliotou, I. (Ed.), Women Migrants from East to West: Gender, mobility and belonging in contemporary Europe, Berghahn Books, Oxford, pp. 195-211.

Cheong, P. H., Edwards, R., Goulbourne, H., Solomos, J. (2007), “Immigration, social cohesion and social capital: A critical review", Critical Social Policy, Vol. 27 No. 1, pp. 24-49.

Cox Jr, T. and Nkomo, S.M. (1990), “Invisible men and women: A status report on race as a variable in organization behavior research", Journal of Organizational Behavior, Vol. 11 No. 6, pp. 419-31.

Cresswell, T. (2002), “Bourdieu's geographies: in memorium”, Environment and planning d: society and space, Vol. 20 No. 4, p.p. 379-82.

Currie, S. (2007), “De-skilled and Devalued: The Labour Market Experience of Polish Migrants in the UK Following EU Enlargement", The International Journal of Comparative Labour Law and Industrial Relations, Vol. 23 No. 1, pp. 83-116.

Dietz, J. (2010) "Introduction to the special issue on employment discrimination against immigrants", Journal of Managerial Psychology, Vol. 25 No. 2, pp. 104-12.

Downey, L. (2008), Racialization of central and east European migrants in Herefordshire, Exeter University, Exeter.

Doyle, N., Hughes, G. and Wadensjo, E. (2006), Freedom of Movement for Workers from Central and Eastern Europe, SIEPS, Stockholm.

Du Bois, W.E.B. (1977/1935), Black Reconstruction in the United States, 1860-1880, Kraus International, New York. 
Dyer, S., McDowell, L., and Batnitzky, A. (2010), “The Impact of Migration on the Gendering of Service Work: The Case of a West London Hotel", Gender, Work and Organization, Vol. 17 No. 6, pp. 635-657.

EC, European Commission (2000), “Report on Progress towards Accession by each of the candidate countries", enlargement strategy paper, European Commission - DG Enlargement, Brussels.

Fairclough, N. (2005), "Critical discourse analysis in transdisciplinary research", in Wodak, R. and Chilton, P. (Ed.) A new agenda in (critical) discourse analysis : theory, methodology and interdisciplinarity, John Benjamins, Philadelphia, PA, pp. 53-70.

Ferge, Z. (2000), “Social security reform: is it a different issue for accession countries? (draft)", paper presented at the conference by CEPII (Paris) and CEPS (Brussels) on the Economic and Social Dimensions of EU Enlargement, 16 November 2000, Brussels.

Frankenberg, R. (1993), White Women, Race Matters: The Social Construction of Whiteness, Routledge, London.

Garner, S. (2006), “The uses of whiteness: What sociologists working on Europe can draw from US research on whiteness", Sociology, Vol. 40 No. 2, pp. 257-75.

Grbich, C. (2007), Qualitative Data Analyses: An Introducton, SAGE, London.

Grimes, D. (2001), "Putting our own house in order: whiteness, change and organization studies", Journal of Organizational Change Management, Vol. 14 No. 2, pp. 132-49.

Guardian (2009), "Give jobs to British people' say Aberthaw power station protesters", Available at: http://www.guardian.co.uk/uk/2009/jan/30/wales (accessed 8 April 2009).

Gunaratnam, Y. (2003), Researching 'race' and ethniciy, SAGE, London.

Hage, G. (1998), White nation: fantasies of white supremacy in a multicultural society, Pluto Press, Sydney. 
Hakak, L.T., Holzinger, I., and Zikic, J. (2010), “Barriers and paths to success: Latin American MBAs' views of employment in Canada", Journal of Managerial Psychology, Vol. 25 No. 2, pp. 159-76.

Healy, G. and Oikelome, F. (2011), Diversity, ethnicity, migration and work: international perspectives, Palgrave Macmillan, Basingstoke.

Healy, G., Bradley, H. and Forson, C. (2011), “Intersectional Sensibilities in Analysing Inequality Regimes in Public Sector Organizations", Gender, Work E Organization, Vol. 18 No. 5, pp. 467-487.

Home Office (HO) (2010), "Worker registration scheme", available at: http://www.ukba.homeoffice.gov.uk/workingintheuk/eea/wrs/ (accessed 11 September 2011).

Hosoda, M., Nguyen, L.T., and Stone-Romero, E.F. (2012), “The effect of Hispanic accents on employment decisions", Journal of Managerial Psychology, Vol. 27 No. 4, pp. 347-64.

Hunter, S. (2010), “What a White Shame: Race, Gender, and White Shame in the Relational Economy of Primary Health Care Organizations in England", Social Politics: International Studies in Gender, State \& Society, Vol. 17 No. 4, pp. 450-476.

Hunter, S., Swan, E., and Grimes, D. (2010), “Introduction: Reproducing and Resisting Whiteness in Organizations, Policies, and Places", Social Politics: International Studies in Gender, State E Society, Vol. 17 No. 4, pp. 407-21.

Ignatiev, N. (1995), How the Irish became white, Routledge, New York.

Imre, A. (2005), “Whiteness in post-socialist eastern Europe”, in Lopez, A.J. (Ed.), Postcolonial whiteness: a critical reader on race and empire, State Univ of New York Pr, NY, pp. 79-102.

Inotai, A. (2002), "Special Challenges and Tasks of 'Eastern' Enlargement", Intereconomics, Vol. 37 No. 4, pp. 180-83. 
Jessop, B. and Oosterlynck, S. (2008), “Cultural Political Economy: on Making the

Cultural Turn without Falling into Soft Economic Sociology", Geoforum, Vol. May No.

3, pp. 1155-69.

Kelly, P. and Lusis, T. (2006), "Migration and the transnational habitus: evidence from Canada and the Philippines", Environment and Planning A, Vol. 38 No. 5, pp. 831-47.

Kideckel, D. A. (1996), “What's in a Name. The Persistence of East Europe as Conceptual Category", Replika. Special Issue. Colonization or Partnership. Eastern Europe and Western Social Sciences., Vol. 21 No. 2, pp. 16-37.

Kiossev, A. (2010), Notes on Self-colonising Cultures, available at: http://www.kultura.bg/media/my html/biblioteka/bgvntgrd/e ak.htm (accessed 12 October 2010).

Kovacs, M. (2001), “Putting Down and Putting Off: The EU's Discursive Strategies in the 1998 and 1999 Follow-Up Reports", in Böröcz, J. and Kovasc, M. (Ed.), Empire's New clothes: Unveiling EU Enlargement, Central Europe Review, Telford, pp. 196-234.

Kovacs, M. and Kabachnik, P. (2001), “The Shedding light on the Quantitative Other:

The EU's Discourse in the Commission Oppinions of 1997", in Böröcz, J. and Kovasc, M. (Ed.), Empire's New clothes: Unveiling EU Enlargement, Central Europe Review, Telford, pp. 147-195.

Kürti, L. (2008), "East and West: The Scholary Divide in Anthropology", Anthropological Notebooks, Vol. 14 No. 3, pp. 25-38.

Kuus, M. (2004), “Europe's estern expansion and the reinscription of otherness in East-Central Europe", Progress in Human Geography, Vol. 28 No. 4, pp. 472-89.

Layder, D. (1998), Sociological Practice: Linking Theory and Social Research, Sage, London.

Layder, D. (1998), Sociological practice: linking theory and social research, SAGE, London. 
Lendvai, N. (2004), “The Weakest Link? EU Accession and Enlargement: Dialoguing EU and Post-Communist Social Policy", Journal of European Social Policy, Vol. 14 No. 3, pp. 319-33.

Lentin, A. and Titley, G. (2011), The crisis of multiculturalism: racism in a neoliberal age, Zed Books, London.

Leonard, P. (2010a), “Old Colonial or New Cosmopolitan? Changing White Identities in the Hong Kong Police", Social Politics: International Studies in Gender, State $\mathcal{E}$ Society, Vol. 17 No. 4, pp. 507-35.

Leonard, P. (2010b), Expatriate identities in postcolonial organizations: working whiteness, Ashgate, Surrey.

Levitt, P. and Schiller, N. G. (2004), “Conceptualizing Simultaneity: A Transnational Social Field Perspective on Society1", International Migration Review, Vol. 38 No. 3, pp. 1002-39.

Lopez, A. J. (2005), "Introduction: Whiteness after Empire”, in Lopez, A. J. (Ed.), Postcolonial whiteness: a critical reader on race and empire, State Univ of New York Pr, NY, pp. 1-30.

Loyal, S. (2009), “The French in Algeria, Algerians in French: Bourdieu, colonialism and migration", The Sociological review, Vol. 57 No. 3, pp. 406-27.

Lutz, H., Phoenix, A. and Yuval-Davis, N.(1995), “Introduction: Nationalism, Racism and Gender - European Crossfires", in Phoenix, A. and Yuval-Davis, N. and Lutz, H. (Ed.), Crossfires: nationalism, racism and gender in Europ, Pluto press, London, pp. 1-25. MacKenzie, R. and Forde, C. (2009) “The rhetoric of the 'good worker' versus the realities of employers' use and the experiences of migrant workers", Work, employment and society, Vol. 23 No. 1, pp. 142-59.

Marc, L. (2009), What's so Eastern about eastern Europe, Oldcastle Books, Harpenden. McCall, Leslie (1992), “Does gender fit? Bourdieu, femininsm, and conceptions of social order", Theory and society, Vol. 21 No.6, pp. 837-67. 
McDowell, L. (2008), “On the Significance of Being White: European Migrant Workers in the British Economy in the 1940s and 2000s", in Dwyer, C. and Bressey, C. (Ed.), New Geographies of Race and Racisms, Ashgate, Hampshire, pp. 51-66.

McDowell, L. (2009), “Old and New European Economic Migrants: Whiteness and Managed Migration Policies", Journal of Ethnic and Migration Studies, Vol. 35 No.1, pp. 19-36.

McDowell, L., Batnitzky, A. and Dyer, S. (2007), “Division, Segmentation, and Interpellation: The Embodied Labors of Migrant Workers in a Greater London Hotel", Economic Geography, Vol. 1 No. 25, pp. 1-25.

McKay, S. (2009) "The Dimensions and Effects of EU Labour Migration in the UK", in Galgoczi, B., Leschke, J. and Watt, A. (ed.) EU Labour Migration sine Enlargement: Trends, Impacts and Policies. Surrey: Ashgate, pp. 29-50.

Metcalfe, B.D. and Woodhams, C. (2012), “Introduction: New Directions in Gender, Diversity and Organization Theorizing: Re-imagining Feminist Post-colonialism, Transnationalism and Geographies of Power", International Journal of Management Reviews, Vol. 14 No. 2, pp. 123-40.

Močnik, R. (2002), “The Balkans as an element in ideological mechanisms”, in Bjelić , D.I. (Ed.), Balkan as metaphor, MIT Press, London, pp. 79-116.

Nkomo, S.M. (1992), “The emperor has no clothes: Rewriting" race in organizations"', Academy of Management Review, Vol. 17 No. 3, pp. 487-513.

Ong, A. (1996), “Cultural Citizenship as Subject-Making”, Current Anthropology, Vol. 37 No. 5, pp. 737-762.

Özbilgin, M. and Tatli, A. (2005), “Book review essay: Understanding Bourdieu's contribution to organization and management studies", Academy of Management Review, Vol. 30 No. 4, pp. 855-69. 
Paynter, R. (2001), "The Cult of Whiteness in Western New England”, in Charles E.

O. (Ed.), Race and the archaeology of identity, University of Utah Press, Salt Lake City, pp.125-145.

Pedersen, L.L. and Samaluk, B. (2012), “Editorial: Different pathways into critical whiteness studies", Graduate Journal for Social Sciences, Vol. 9 No. 1, pp. 9-21.

Ponzanesi, S. and Blaagaard, B.B. (2011), "Introduction: In the Name of Europe", Social Identities, Vol. 17 No. 1, pp. 1-10.

Puwar, N. (2004), Space invaders: race, gender and bodies out of place, Berg, Oxford.

Roediger, D. R. (1991), Wages of whiteness: race and the making of the American working class, Verso, London.

Samaluk, B. (2009), "Intersectional racialization and racisms: the case of Slovene immigrants in the UK", MA dissertation, London MET, London.

Samaluk, B. (2011), “Racialised 'price-tag': commodification of migrant labour from post-socialist Europe and its effects on the UK labour market", paper presented at PEDEC workshop Labour Market Vulnerability, Precarious Work and Migrant Workers in the Economic Downturn, 16 November, London, UK, available at: http://www.geog.qmul.ac.uk/pedec/outputs.html (accessed 12 February 2012).

Sher, A. (2001), “A Di-Vision of Europe: The European Union Enlarged”, in Böröcz, J. and Kovasc, M. (Ed.), Empire's New clothes: Unveiling EU Enlargement, Central Europe Review, Telford, pp. 235-272.

Skeggs, B. (2004), “Context and Background: Pierre Bourdieu's analysis of Class, Gender and Sexuality", in Adkins, L. and Skeggs, B. (Ed.), Feminism after Bourdieu, Blackwell, Oxford, pp. 19-34.

Slovova, K. (2006), “Looking at Western Feminisms through the Double Lens of Eastern Europe and the Third World", in Lukić, J., Regulska, J. and Zaviršek, D. (Ed.), Women and Citizenship in Centra and Eastern Europe, Ashgate: Aldershot, pp. 245-63 . 
Stevenson, B. (2007), A8 Nationals in Glasgow, City Council, Glasgow.

Strauss A.L. and Corbin, J. (1990), Basics of Qualitative Research, Sage, London.

Tatli, A. and Özbilgin, M. (2012), "Surprising intersectionalities of inequality and privilege: the case of the arts and cultural sector", Equality, Diversity and Inclusion: An International Journal, Vol. 31 No. 3, pp. 249 - 265.

Tatli, A. and Özbilgin, M.F. (2012), “An Emic Approach to Intersectional Study of Diversity at Work: A Bourdieuan Framing", International Journal of Management Reviews, Vol. 14 No.2, pp. 180-200.

Temple, B. (1997), “Watch your tongue: issues in translation and cross-cultural research", Sociology, Vol. 31 No. 3, pp. 607-18.

Temple, B. and Edwards, R. (2008), “Interpreters/translators and cross-language research: Reflexivity and border crossings", International Journal of Qualitative Methods, Vol. 1 No. 2, pp. 1-12.

Todorova, M. (1997), Imagining the Balkans, Oxford University Press, Oxford.

Tutti, P. (2010), "Narratives of origins and the Emergance of the European Union", in Lessard,H., Johnson, R. and Webber, J. (Ed.), Storied Communities: Narratives of Contact and Arrival in Constituting Political Community, UBC Press, Vancouver, pp. 229-244.

Vaughan-Whitehead, D. (2003), EU enlargement versus social Europe? : the uncertain future of the European social model, Elgar, Cheltenham.

Vertovec, S. (2006), “The Emergence of Super-Diversity in Britain”, working paper [No. 25], COMPAS, Oxford.

Weiss, A. (2011), “Racist Symbolic Capital: A Bourdieuan Approach to the Analysis of Racism", in Hund, W. D., Krikler, J., and Roediger, D. R. (Ed.), Wages of whiteness $\mathcal{E}$ racist symbolic capital, Lit, London, pp. 37-56.

Wills, J., Datta, K., Evans, Y., Herbert, J., May, J. and McIlwaine, C. (2010), Global cities at work: new migrant divisions of labour, Pluto Press, England. 